\title{
Cari Açığı Belirleyen Faktörler: Türkiye Ekonomisi Üzerine Ampirik Bir Uygulama
}

\section{Factors Determining the Current Account Deficit: An Empirical Application on Turkey Economy}

\author{
Kemal Aka a,* \\ ${ }^{a}$ Dr. Öğr. Üyesi, Marmara Üniversitesi, Bankacılık ve Sigortacılık Yüksekokulu, Sermaye Piyasası Bölümü, 34730, İstanbul/Türkiye. \\ ORCID: 0000-0001-6290-1451
}

\section{MAKALE BİLGISİ}

\section{Makale Geçmişi:}

Başvuru tarihi: 19 Kasım 2019

Düzeltme tarihi: 06 Mayıs 2020

Kabul tarihi: 14 Mayıs 2020

Anahtar Kelimeler:

Cari İşlemler Dengesi

Doğrudan Yabancı Yatırım

En Küçük Kareler Yöntemi
ÖZ

Tarih boyunca Türkiye ekonomisinin en önemli problemlerinde birisi şüphesiz cari açık sorunu olmuştur. Cari açığın GSYH oranının belli bir değer üzerine çıkması kriz belirtisi olacağından dolayı ekonomi yönetimlerinin en önemli amaçlarından birisi cari açık sorununu çözmek olmuştur. Bu çalışma Türkiye'de cari açığın belirleyicilerini tespit etmeyi amaçlamaktadır. Bu kapsamda Dünya Bankası, TCMB ve TÜiK'ten 1990-2018 dönemine ait yıllık veriler kullanılarak Türkiye'de cari açığın belirleyicileri tespit edilmiştir. Çalışmanın ekonometrik analiz kısmında ise En Küçük Kareler(EKK) yöntemi kullanılmıştır. EKK uygulamadan önce serilerin durağanlıkları ve EKK için gerekli varsayımlar test edilmiş, test sonucunda serilerin durağan olduğu ve gerekli varsayımların sağlandığı görülmüştür. Çalışmanın sonucunda ihracatın ithalatı karşılama oranı, doğrudan yabancı ve portföy yatırımlarının cari açığı azalttığı, dışa açıklık oranının ise cari açığı artırdığı sonucuna ulaşılmıştır

\section{A B S T R ACT}

Throughout history, one of the most important problems of Turkey's economy has been the problem of the current deficit. One of the most important objectives of the economic management was to solve the current deficit problem, since the current deficit would be a sign of the crisis as the GDP ratio exceeds a certain value. This study aims to identify the determinants of the current deficit in Turkey. In this context, analysis was made with the help of the Least Squares Method, using annual data for the period 1990-2018. As a result of the study, it was concluded that the ratio of exports to imports, direct foreign and portfolio investments decreased the current deficit, openness ratio increased the current deficit.

\section{Keywords:}

Current Account Balance,

Foreign Direct Investment,

Least Squares Method

\section{Giriş}

Cari açık ekonomik istikrarın devamlılığı için büyük önem taşımaktadır. Son yıllarda gerek kamuoyunda gerekse makroekonomi literatüründe üzerinde en çok tartışılan konuların başında cari açık sorunu gelmektedir. Cari açık, tasarruflar ile yatırımların karşılanamadığı ve yatırımların yurtdışından sermaye girişleriyle karşılandığı zaman ortaya çıkmaktadır. Bir ülkenin cari açığın GSYH içerisindeki payının artması, ülkenin dışarıya bağımlılığını artıracak ve dışarıda oluşabilecek dalgalanmalar karşısında ülkeyi daha kırılgan hale getirecektir. Çünkü cari açıkta meydana gelecek artış finansal kriz sinyali olarak algılanmakta ve makroekonomik performansta zayıflama eğilimlerini ortaya çıkarmaktadır.
Literatür incelendiğinde görülmektedir ki; cari işlemler dengesinin GSYH'ya oranı $\% 5$ ve daha üzeri olursa ekonominin durumu riskli görülmektedir. Yapılan bazı çalışmalarda, cari işlemler dengesinin GSYH değerine oranı \%5'e yaklaşması durumunda ise üç- dört yıllık bir dönemde gelir büyümesinde yavaşlama ve reel döviz kurunda aşınma olabileceğine dair görüşler bulunmaktadır(Peker, 2009: 165). Bununla ilgili olarak Summers(2004), cari açığın GSYH'ya oranının yüzde 5'in üzerinde olması durumda ekonominin tehlikede olduğunu belirtmiştir(Clarida, 2005: 133). Bu sebeplerden ötürü cari işlemler dengesi, ekonomi yönetiminde karar vericilerin,

\footnotetext{
*Sorumlu yazar/Corresponding author

e-posta: kemal.aka@marmara.edu.tr
} 
ileriye dönük alacağı kararlarda belirleyici bir rol üstlenmektedir(Calderon v.d., 2002: 1).

Cari açık, bir ekonominin gelecekteki davranışı için ana öncü göstergelerden biri olarak kullanılmakta ve politika yapıcıların günlük karar sürecinin önemli bir parçası olmaktadır. Cari açık, ülkeye yatırım yapacak yerli ve yabancı yatırımcılara yol göstermesi açısından önemli bir ekonomik göstergedir. Cari açık, aşırı iç talep, yurtiçi tasarruf eksikliği, aşırı değerlenmiş döviz kurları, ithalat ve ihracata ilişkin devlet politikaları, iç üretim kapasitesi gibi faktörlerden kaynaklanabilir. Cari açığı olan bir ülke, kazandığından daha çok harcadığı anlamına gelmektedir. Başka bir ifadeyle, tüketiciler, firmalar ve hükümetler toplu olarak yerli üretimden ve net dış yatırımlardan elde edilen kazançtan daha fazlasını harcaması durumunda cari açık ortaya çıkmaktadır(Obstfeld ve Rogoff, 1996: 5; Çinko ve Demirci, 2017: 149). Belli bir dönemlik ya da geçici cari açık ekonomi için ciddi bir problem değildir ve kolayca düzeltilebilir. Fakat büyük çapta ve kronik bir cari açık, ekonominin tehlikede olduğunu gösterir ve politikacıların önlem almadığı takdirde ülkeyi ekonomik krizle karşı karşıya bırakır.

Büyük ve kalıcı cari açık ekonomiyi birçok yönden etkilemektedir. Ülke ekonomisinde cari açık bulunuyorsa, ürettiğinden daha fazlasını kullandığı ve diğer ülkelere yaptığı ihracattan daha fazla mal ithal ettiği anlamına gelmektedir. İç talep yüksek olduğunda ve yerli üreticiler bu talebi karşılayamadığında, ithal edilen mal ve hizmetlere olan talep artar ve sonuçta ticarette ve cari açık tarafinda bir artışa neden olur. $\mathrm{Bu}$ durum yerel para biriminin değer kaybetmesine, döviz kurunun da değerlenmesine sebep olur. Yerel para biriminin değer kaybetmesi yabancilar için daha düşük fiyatla mal ve hizmet alımını kolaylaştıracağı için ihracat tarafinda olumlu bir etki yapar. Bununla birlikte yerel paranın değer kaybetmesinden dolayı yurtdışından alınacak mal ve hizmet daha pahalı hale geleceğinden dolayı ithalat tarafinı da olumsuz etkilenmektedir. Dolayısıyla kurun değer kazanması ile ihracatın artması ve ithalatın azalması, cari açığın azalmasına neden olacaktır. Fakat ülke, artan dış talep karşısında yeterli üretim kapasitesine sahip değilse, ihracat ve ithalat dengesini etkileyecek, dolayısıyla cari açık artmaya devam edecektir(Gulzar v.d., 2007: 664).

Türkiye cari açık problemi çeken ülkeler arasında yer almaktadır. Bu sorun Türkiye için kronik bir sorun haline gelmiştir. Şüphesiz bu durumun en önemli sebebi enerjide dışa bağımlılığın yüksek olmasındandır. TÜİK verilerinden Türkiye ekonomisinde en önemli ithalat kalemleri incelendiğinde ilk sırayı petrol ve doğalgaz alırken, ikinci sırada sanayide kullanılan hammadde ve ara malların olduğu görülmektedir. Türkiye ekonomisi için sanayinin işlemesi ve büyümenin devamı için hem enerji ithalatı hem de hammadde ve ara mal son derece önemlidir. Çünkü Türk sanayisi montaj yapan veya ithal ettiği ara malına kısmi değer katıp ihraç eden konumundadır. Bu sebeple cari açığın azaltılması için ya ülke olarak kendi enerjimizi kendi petrol ve doğalgazımızı üretmemiz ya da sanayide kullandığımız hammadde ve ara malları kendimizin üretmesi gerekmektedir.
1990 yılından günümüze Türkiye'nin cari işlemler dengesi rakamları incelendiğinde 91,94, 98 ve 2001 yılları hariç diğer yıllarda cari açığın olduğu görülmektedir(Bkz. Tablo 1).

Tablo 1. Türkiye'de Cari İşlemler Dengesi (1990-2018)

\begin{tabular}{|c|c|c|c|c|c|}
\hline & $\begin{array}{c}\text { Cari İşlemler } \\
\text { Dengesi/GSYH }\end{array}$ & $\begin{array}{c}\text { Cari } \\
\text { Isşlemler } \\
\text { Dengesi }\end{array}$ & & $\begin{array}{c}\text { Cari İşlemler } \\
\text { Dengesi/GSYH }\end{array}$ & $\begin{array}{c}\text { Cari } \\
\text { İşlemler } \\
\text { Dengesi }\end{array}$ \\
\hline & $\%$ & Milyon\$ & & $\%$ & Milyon\$ \\
\hline 1990 & $-1,74$ & -2.625 & 2005 & $-4,18$ & -20.980 \\
\hline 1991 & 0,17 & 250 & 2006 & $-5,64$ & -31.168 \\
\hline 1992 & $-0,61$ & -974 & 2007 & $-5,47$ & -36.949 \\
\hline 1993 & $-3,57$ & -6.433 & 2008 & $-5,16$ & -39.425 \\
\hline 1994 & 2,01 & 2.631 & 2009 & $-1,76$ & -11.358 \\
\hline 1995 & $-1,38$ & -2.338 & 2010 & $-5,78$ & -44.616 \\
\hline 1996 & $-1,34$ & -2.437 & 2011 & $-8,94$ & -74.402 \\
\hline 1997 & $-1,39$ & -2.638 & 2012 & $-5,49$ & -47.963 \\
\hline 1998 & 0,73 & 2.000 & 2013 & $-6,70$ & -63.642 \\
\hline 1999 & $-0,36$ & -925 & 2014 & $-4,67$ & -43.610 \\
\hline 2000 & $-3,63$ & -9.920 & 2015 & $-3,74$ & -32.145 \\
\hline 2001 & 1,88 & 3.760 & 2016 & $-3,84$ & -33.139 \\
\hline 2002 & $-0,26$ & -626 & 2017 & $-5,56$ & -47.347 \\
\hline 2003 & $-2,42$ & -7.554 & 2018 & $-3,54$ & -27.115 \\
\hline 2004 & $-3,51$ & -14.198 & & & \\
\hline
\end{tabular}

Kaynak: WorldBank

Tablo 1 incelendiğinde 1994 ve 2001 yıllarında Türkiye'de yaşanan ekonomik kriz dönemlerinde cari işlemler dengesinin fazla verdiği görülmektedir. Kriz dönemlerinde ulusal paranın değer kaybetmesinden dolayı yurtiçindeki mal ve hizmetlerin yurtdıșına göre ucuzlaması ithalatın azalmasina ve ihracatın artmasına sebep olmaktadır. Bu durum da cari işlemler dengesinin üzerinde olumlu etkisi olmaktadır. Türkiye için de kriz dönemlerinde cari fazla verilmesi ihracat ve ithalattaki söz konusu bu değişim ile açıklanabilir. Cari işlemler dengesi 1994 yılında 2.6 milyar \$ fazla verilirken, 2001 yılında da 3.7 milyar \$ fazla verdiği görülmektedir. 2001 yılından sonraki yıllarda cari açığın 2008 yılında yaşanan küresel krize kadar devamlı arttığı görülmektedir. 2008 yılında küresel krizinde etkisiyle cari açık bir önceki yıla göre yaklaşık 28 milyar \$ azalarak 2009 yılında 11.3 milyar \$ açık gerçekleşmiştir. 2011 yılında 74.4 milyar \$ ile son 28 yilın en yüksek seviyesine ulaşan cari açık yıllar itibariyle azalarak 2018 
y1lında kurda yaşanan dalgalanmalarında etkisiyle 27.1 milyar \$ seviyesine kadar gerilemiştir.

Özetle, cari işlemler dengesindeki değişim, ülke ekonomisinin makroekonomik performansı hakkında önemli bilgiler aktarmakta ve makroekonomik politikalardaki değişimler hakkında faydalı bilgiler sağlamaktadır. Gelişmekte olan ülkelerin çoğunda devam eden cari işlemler dengesizlikleri, ekonomistler ve politika yapıcılar arasında cari işlemler dengesizliklerinin makroekonomik sonuçlardaki rolü ve önemi konusunda net bir anlayışa sahip olmaları konusunda ilgi uyandırmıştır(Kwalingana ve Nkuna, 2009: 3). Bu durum cari açı̆̆ın belirleyicileri üzerine yapılacak çalışmalarında önemini artırmıştır. Dolayısıyla bu çalışmanın amacı, cari açık ile teorik ve literatür tarafindan önerilen çeşitli makroekonomik değişkenler arasındaki bağlantıyı incelemek ve Türkiye özelinde cari açığı belirleyen faktörlerin neler olduğunu ortaya koymaktır.

\section{Literatür Taraması}

Literatürde cari açığın ya da cari işlemler dengesinin belirleyicilerini inceleyen pek çok çalışma bulunmaktadır. Çeşitli ekonometrik modeller uygulanarak yapılan çalışmalardan çeşitli değişkenlerle çeşitli sonuçlar elde edilmiştir. Yapılan çalışmaların bazılarında örneklem tek ülke olurken, bazı çalışmalarda ise örneklemin birden fazla ülke olduğu görülmektedir. Birden fazla ülkeler için yapılan çalışmaların ise genellikle gelişmiş ülkeler, gelişmekte olan ülkeler ve petrol ihraç eden ülkeler olduğu görülmektedir.

Khan ve Knight, yaptıkları çalışmada petrole sahip olmayan 32 ülkeden 1973-1980 dönemine ait verileri kullanarak cari işlemler dengesinin belirleyicilerini incelemişlerdir. Çalışmanın sonucunda dış ticaret dengesindeki azalma, sanayi ülkelerindeki ekonomik yavaşlama, reel faiz oranlarındaki keskin artış gibi dış faktörlerin ve mali açıklardaki artış, reel döviz kurunun değer kazanması gibi iç faktörlerin petrole sahip olmayan 32 ülke ekonomisinin cari işlemler pozisyonun kötüleşmesine sebep olduğunu ortaya koymuşlardır(Khan ve Knight, 1983:819).

Debelle ve Faruqee, yaptıkları çalışmada cari açığın belirleyicilerini 1971-1993 dönemine ait 21 gelişmiş ülkenin verilerini kullanarak tespit etmeye çalışmışlardır. Çalışmanın sonucunda cari açık üzerinde kısa dönemde reel döviz kurunun, konjonktürel dalgalanmalarının ve dış ticaret dengesinin etkisi olduğu, uzun dönemde ise kalkınma süreci ve demografik değişkenlerin etkisi olduğu sonucuna ulaşmışlardır(Debelle ve Faruqee, 1996: 1).

Calderon ve diğerleri yaptıkları çalışmada cari açık ile literatürde yer alan ekonomik değişkenler arasındaki ilişkiyi 44 gelişmekte olan ülkeden 1966-1994 dönemine ait verileri kullanarak test etmişlerdir. Çalışmanın sonucunda yurtiçi iktisadi büyümenin, dış ticaret dengesindeki kötüleşmenin ve reel döviz kurundaki artışların cari açığı artırdığını, kamu ve özel tasarruf oranlarındaki artışın ve ihracattaki artışın cari açığı azalttığını ortaya koymuşlardır. Bununla birlikte sanayileşmiş ülkelerdeki büyüme oranının artmasının gelişmekte olan ülkelerde cari açığı azalttığını ve uluslararası faiz oranlarının azalmasının ise gelişmekte olan ülkelerde cari açığı artırdığını ortaya koymuşlardır(Calderon v.d., 1999: 22-23).

Chinn ve Prasad, yaptıkları çalışmada gelişmiş ve gelişmekte olan ülkelerin verilerini kullanarak cari işlemlerin belirleyicilerini incelemişlerdir. Çalışmanın sonucunda gelişmekte olan ülkelerde bütçe dengesi, finansal derinlik ve diş ticaret dengesindeki oynaklık ile cari işlemler dengesi arasında pozitif, dışa açıklık oranı ile cari işlemler dengesi arasında ise negatif ilişki olduğunu ortaya koymuşlardır(Chinn ve Prasad, 2000: 25-26).

Aristovnik, yaptığı çalışmada Doğu Avrupa ve eski Sovyetler Birliği'ndeki seçilmiş ülkelerdeki cari açığın temel faktörlerini incelemiştir. Çalışmanın sonucunda GSYH büyümesi, yaşlı bağımlılık oranı ve reel efektif döviz kurunun cari işlemler dengesi üzerinde olumsuz etkisi olduğunu, başka bir ifadeyle, söz konusu değişkenlerin cari açığı artırdığı sonucuna ulaşmıştır. Diğer taraftan nispi gelir, bütçe dengesi, diş ticaret dengesi ve dış borç oranının cari işlemler dengesi üzerinde olumlu, başka bir ifadeyle cari açı̆̆1 azalttığı sonucuna ulaşmıştır(Aristovnik, 2006: 10-14).

Gulzar ve diğerleri yaptıkları çalışmada Pakistan'da cari işlemler dengesine etki eden faktörlerin belirleyicilerini incelemişlerdir. Çalışmanın sonucunda, diş ticaret dengesindeki \%1'lik artışın cari işlemler dengesini \%1.37 oranında artırdığı, yurtiçi tasarruflarda \%1'lik artışın cari işlemler dengesini \%0.95 artırdığı, işçi gelirlerinde \%1'lik artışın car işlemler dengesini \%2.86 artırdığı ve son olarak toplam tüketimdeki \%1'lik artışın cari işlemler dengesini $\% 0.31$ oranında azalttığı sonucuna ulaşmışlardır(Gulzar v.d., 2007: 669).

Bitzis ve diğerleri yaptıkları çalışmada Yunanistan ekonomisindeki cari açı̆̆ı etkileyen faktörleri incelemişlerdir. Çalışmanın sonucunda bütçe açığı, petrol fiyatları ve reel efektif döviz kurunun cari açık üzerinde olumlu, faiz oranı, nakliye fiyatları ve dış ticaret dengesinin ise cari açık üzerinde olumsuz etkisi olduğu sonucuna ulaşılmışlardır(Bitzis v.d., 2008: 120-121).

Herwartz ve Siedenburg, yaptıkları çalışmada cari işlemler dengesinin belirleyicilerini 16 OECD ülkeden panel verileri kullanarak ampirik olarak incelemişlerdir. Çalışmanın sonucunda cari işlemler dengesini önemli ölçüde etkileyen üç ekonomik değişkenin olduğunu ortaya koymuşlardır. Söz konusu bu değişkenlerin de bütçesi dengesi, yurt içi üretim açığı ve diş ticaret dengesi olduğunu ifade etmişlerdir(Herwartz ve Siedenburg, 2007: 349).

Morsy, yaptı̆̆ı çalışmada petrol ihraç eden ülkelerin verilerini kullanarak orta vadeli cari işlemler dengesinin belirleyicilerini incelemiştir. Çalışmanın sonucunda petrol ihraç eden ülkelerin denge cari işlemler dengesinin belirlenmesinde önemli olan faktörlerin bütçe dengesi, petrol fiyatları, petrol zenginlikleri, yaşlı bağımlılık oranı ve petrol üretimindeki olgunluk derecesi olduğunu ortaya koymuştur. Bütçe dengesi ve petrol fiyatları ile cari işlemler dengesi arasında pozitif ilişki olduğunu, yaşlı bağımlılık oranı, petrol zenginliği ve petrol üretiminde 
olgunluk derecesi ile cari işlemler dengesi arasında ise negatif ilişki olduğunu ortaya koymuştur(Morsy, 2009: 8).

Tablo 2. Cari İşlemler Dengesi Üzerine Literatürde Yapılan Çalışmalar

\begin{tabular}{|c|c|c|c|}
\hline Çalışmanın Adı - Yazar & Değişkenler & Model & Sonuç \\
\hline $\begin{array}{l}\text { Determinants of Current Account } \\
\text { Balances of Non-Oil Developing } \\
\text { Countries in the 1970s: An Empirical } \\
\text { Analysis(1983) } \\
\text { - } \\
\text { Mohsin S. KHAN ve Malcolm D. } \\
\text { KNİGHT }\end{array}$ & $\begin{array}{l}\text { Bağımlı Değ: r Cari } \\
\text { İşlemler Dengesi } \\
\text { Bağımsız Değ: Dış Ticaret } \\
\text { Dengesi, sanayileşmiş } \\
\text { ülkelerde büyüme oranı, } \\
\text { reel faiz oranı, mali } \\
\text { durum, reel efektif döviz } \\
\text { kuru }\end{array}$ & $\begin{array}{l}\text { Havuzlanmış } \\
\text { Model }\end{array}$ & $\begin{array}{l}\text { Diş ticaret dengesindeki azalma, sanayi } \\
\text { ülkelerindeki ekonomik yavaşlama, reel faiz } \\
\text { oranlarındaki artış gibi dış faktörlerin ve mali } \\
\text { açıklardakiartış, döviz kurunun değer kazanmas1 } \\
\text { gibi iç faktörlerin petrole sahip olmayan } 32 \text { ülke } \\
\text { ekonomisinin cari işlemler pozisyonun } \\
\text { kötüleşmesine sebep olduğunu ortaya } \\
\text { koymuşlardır. }\end{array}$ \\
\hline
\end{tabular}

\begin{tabular}{|c|c|c|c|}
\hline $\begin{array}{l}\text { "What Determinants the Currnet } \\
\text { Account? A cross- Sectional and } \\
\text { Panel Data Approach(1996) } \\
\text { - } \\
\text { Guy DEBELLE ve Hamid } \\
\text { FAREQUEE }\end{array}$ & 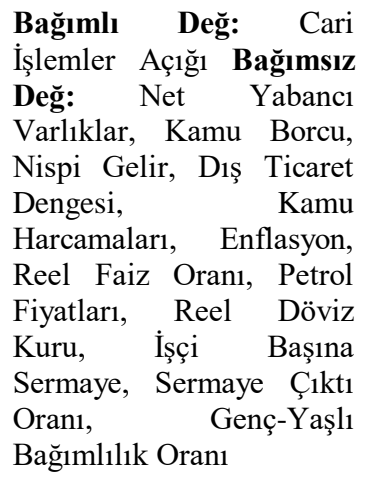 & Panel Regresyon & $\begin{array}{l}\text { Cari açık üzerinde kısa dönemde reel döviz } \\
\text { kurunun, konjonktürel dalgalanmaların ve dış } \\
\text { ticaret dengesinin etkisi olduğu, uzun dönemde } \\
\text { ise kalkınma süreci ve demografik değişkenlerin } \\
\text { etkisi olduğu sonucuna ulaşmışlardır. }\end{array}$ \\
\hline $\begin{array}{l}\text { "Determinants of Current Account } \\
\text { Deficits in Developing Countries" } \\
\text { (1999) } \\
\text { - } \\
\text { Cesar Augusto Calderon, Alberto } \\
\text { CHONG, ve Norman LOAYZA }\end{array}$ & $\begin{array}{l}\text { Bağımlı Değ: Cari } \\
\text { İşlemler Açı̆̆ı Bağımsız } \\
\text { Değ: Döviz Kuru, Kamu } \\
\text { ve Özel Tasarruf, Dış } \\
\text { Ticaret Dengesi, Büyüme } \\
\text { Oranı, Faiz Oranları, } \\
\text { İhracat Oranı }\end{array}$ & GMM & $\begin{array}{l}\text { Yurtiçi iktisadi büyümenin, dış ticaret } \\
\text { dengesindeki kötüleşmenin ve reel döviz } \\
\text { kurundaki artışların cari açığı artırdığını, kamu } \\
\text { ve özel tasarruforanları ve ihracattaki artışın cari } \\
\text { açığı azalttığını ortaya koymuşlardır. Bununla } \\
\text { birlikte sanayileşmiş ülkelerdeki büyüme } \\
\text { oranının artmasının gelişmekte olan ülkelerde } \\
\text { cari açı̆̆ı azalttığını ve uluslararası faiz } \\
\text { oranlarının azalmasının ise gelişmekte olan } \\
\text { ülkelerde cari açığ ar artırdığını ortaya } \\
\text { koymuşlardır. }\end{array}$ \\
\hline
\end{tabular}

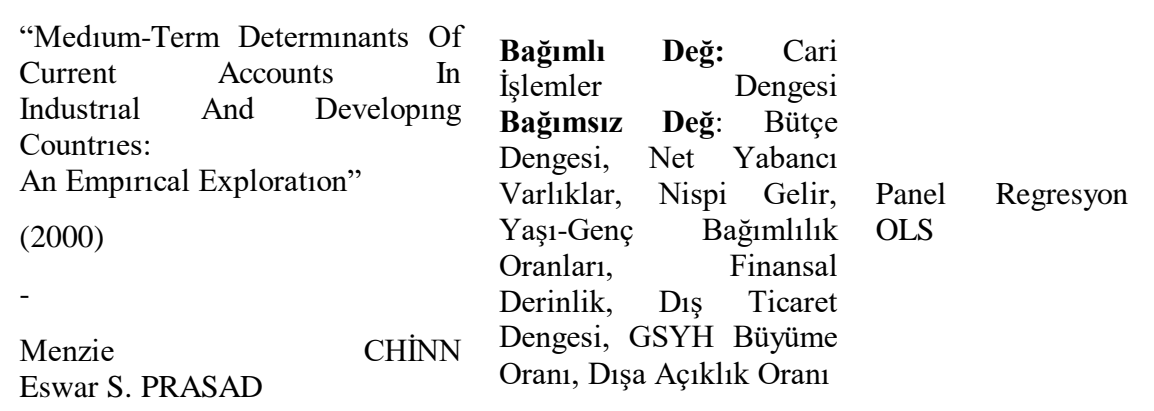

Gelişmekte olan ülkelerde cari işlemler dengesi ile bütçe dengesi, finansal derinlik ve dış ticaret dengesindeki oynaklık arasında pozitif, dışa açıklık oranı ile arasında ise negatif ilişki olduğunu ortaya koymuşlardır.

"The Determinants of the Greek

Current Account Deficit: The

EMU Experience"

(2008)

Grigorios BİTZIS,

John M. PALEOLOGOS ve Fiyatları,

Christos PAPAZOGLOU
Bağımlı Değ: Cari İşlemler Açı̆̆ı Bağımsız Değ: Bütçe Açığı, Reel Efektif Döviz Kuru, Reel Faiz Oran1, Petrol Fiyatlar1, Nakliye Fiyatları, Dış Ticaret MVAR
Cari açık üzerine bütçe açığı, petrol fiyatları ve reel efektif döviz kurunun pozitif, faiz oranı, nakliye fiyatları ve dış ticaret dengesinin ise negatif etkisi olduğuna ulaşılmıştır. 


\begin{tabular}{|c|c|c|c|}
\hline $\begin{array}{l}\text { "The Determinants and } \\
\text { Excessiveness of Current Account } \\
\text { Deficits in Eastern Europe and the } \\
\text { Former Soviet Union"(2006) } \\
\text { - } \\
\text { Aleksander ARISTOVNIK }\end{array}$ & 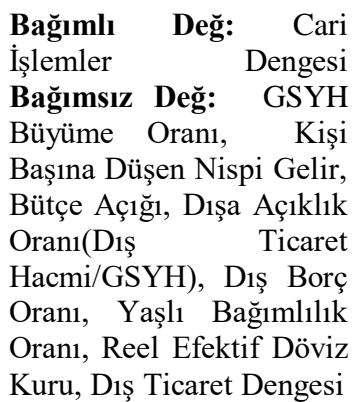 & $\begin{array}{l}\text { GMM-IV } \\
\text { Tahmincisi }\end{array}$ & $\begin{array}{l}\text { Cari açık ile GSYH büyümesi, yaşlı bağımlılık } \\
\text { oranı ve reel efektif döviz kuru arasında } \\
\text { pozitif, nispi gelir, bütçe dengesi, dış ticaret } \\
\text { dengesi ve dı̧ borç oranı ile arasında ise } \\
\text { negatif ilişki olduğu sonucuna ulaşılmıştır. }\end{array}$ \\
\hline $\begin{array}{l}\text { "The Current Account Balance of } \\
\text { Pakistan 1972-2005: A } \\
\text { Cointegration Analysis"(2007) } \\
\text { - } \\
\text { Saqib GULZAR, Hui Xiao } \\
\text { FENG ve Wang YAJIE }\end{array}$ & $\begin{array}{lrr}\text { Bağımlı } & \text { Değ: } & \text { Cari } \\
\text { İşlemler } & \text { Dengesi } \\
\text { Bağımsız Değ: } & \text { D1ş } \\
\text { Ticaret Dengesi, Işçi } \\
\text { Geliri, Toplam Tüketim, } \\
\text { Ulusal Tasarruf }\end{array}$ & $\begin{array}{l}\text { Johansen } \\
\text { Cointegration Test }\end{array}$ & $\begin{array}{l}\text { Cari işlemler dengesi ile dış ticaret dengesi, } \\
\text { yurtiçi tasarruflar ve işçi gelirleri arasında } \\
\text { pozitif, toplam tüketim ile arasında ise negatif } \\
\text { ilişki bulunmuştur. }\end{array}$ \\
\hline
\end{tabular}

\begin{tabular}{lrl}
\hline & \multicolumn{3}{l}{ Bağımlı Değ: Cari İslemler } \\
“Current Account Determinants & Dengesi Bağımsı Değ: \\
for & Oil- & Bütçe Dengesi, Yaşlı \\
Exporting Countries” & Bağımlılı Oranı, Nüfus Pooled OLS, Fixed \\
$(2009)$ & Büyüme, Net Yabancı Effects Techniques, \\
& Varlıklar, Petrol Fiyatları, Generalized Method \\
- & Ekonomik Büyüme, Nispi of Moments (GMM) \\
Hanan MORSY & Gelir, Petrol Serveti, Petrol \\
& Üretiminde Olgunluk \\
& Derecesi
\end{tabular}

Cari işlemler dengesi ile bütçe dengesi ve petrol fiyatları arasında pozitif, yaşlı bağımlılık oranı, petrol serveti ve petrol üretiminde olgunluk derecesi ile arasında ise negatif ilişki bulunmuştur.

\footnotetext{
"The Determinants of Current Bağımlı Değ: Cari İşlemler Account Dengesi Bağımsız Değ: $\begin{array}{ll}\text { Imbalances in Malawi"(2009) } & \text { Dengesi Bağımsız Değ: } \\ \text { Reel Efektif Döviz Kuru, }\end{array}$ - $\quad$ Bütçe Açığı, Diş Borç, Dişa Samson KWALINGANA ve Açıklık Oranı, Dış Ticaret Onelie NKUNA Dengesi,

Cari işlemler dengesi ile reel efektif döviz kuru, diş borç stoku ve dış ticaret dengesi ile cari işlemler dengesi arasında pozitif, dışa açıklık oranı ile arasında ise negatif bir ilişki bulunmuştur.
}

\begin{tabular}{|c|c|c|}
\hline $\begin{array}{l}\text { “Türkiye’de } \\
\text { Belirleyicileri: }\end{array}$ & $\begin{array}{l}\text { Bağıml Değ: Cari Açık } \\
\text { Bağımsız Deği: Petrol } \\
\text { Fivatları, Para arzı, İhracatın }\end{array}$ & \multirow{7}{*}{$\begin{array}{l}\text { Cari açık ile ihracatın ithalatı karşılama oranı } \\
\text { arasında negatif, para arzı ve petrol fiyatları } \\
\text { ile arasında ise pozitif ilişki bulunmuştur. }\end{array}$} \\
\hline \multirow[t]{2}{*}{ Modelleri İle Bir İnceleme"(2009) } & İthalat1 Karş1lama Oranı, & \\
\hline & Enflasyon, Enflasyon MGARCH & \\
\hline & Belirsizliği, Döviz Kuru, Modellerı & \\
\hline Seyfettin ERDOĞAN ve & Döviz Kuru Belirsizliği, & \\
\hline BOZKURT & Doğrudan $\quad$ Yabanc1 & \\
\hline & Yatırımlar & \\
\hline
\end{tabular}

“Türkiye'de Ekonomik Büyüme ve Cari

İşlemler Dengesi İlişkisi”(2009)

Cari İşlemler Dengesi ve Granger

Büyüme oranının artmasının cari işlemler Ekonomik Büyüme dengesinde bozulmalara yol açtığını, başka bir

Osman Murat TELATAR ve Analizleri ifadeyle cari açı̆̆ı artırdığı sonucuna

Harun TERZI 


\begin{tabular}{|c|c|c|c|}
\hline $\begin{array}{l}\text { "Gelişmekte Olan Ülkelerde Cari } \\
\text { Açığın Belirleyicileri: } \\
\text { Panel Veri Analizi”(2011) } \\
\text { - } \\
\text { Yusuf BAYRAKTUTAN ve } \\
\text { Işıl DEMIRTAŞ }\end{array}$ & $\begin{array}{l}\text { Bağımlı Değ: Cari İşlemler } \\
\text { Açığı, Bağımsız Değ: } \\
\text { Büyüme Oranı, Nispi Gelir, } \\
\text { Finansal Derinlik, Bütçe } \\
\text { Açığı, Dış Borç Oranı, Reel } \\
\text { Döviz Kuru, Yatırımlar, } \\
\text { Kamu Harcamaları, Dış } \\
\text { Ticaret Dengesi, Dışa Açıklık } \\
\text { Oranı Dünya Büyüme Oranı, } \\
\text { Dünya Faiz Oranlarındaki } \\
\text { Artış }\end{array}$ & Panel Veri Analizi & $\begin{array}{l}\text { Cari açık ile büyüme oranı, yatırımlar ve kamu } \\
\text { harcamaları arasında pozitif, dış ticaret } \\
\text { dengesinde iyileşme, dişa açıklı oranı, dünya } \\
\text { büyüme oranı } \\
\text { faiz oranları ile arasında ise negatif ilişk } \\
\text { bulunmuştur. }\end{array}$ \\
\hline $\begin{array}{l}\text { "The Relationship } \\
\text { Current Deficit and Economic } \\
\text { Growth: An Empirical Study on } \\
\text { Turkey"(2015) } \\
\text { - } \\
\text { Funda YURDAKULA ve Bengisu } \\
\text { UCAR }\end{array}$ & $\begin{array}{l}\text { Bağımlı Dĕ̆: Cari İşlemler } \\
\text { Açı̆̆ı Bağımsız Değ: } \\
\text { Ekonomik Büyüme Oranı }\end{array}$ & $\begin{array}{l}\text { Granger } \\
\text { Nedensellik ve VAR } \\
\text { analizleri }\end{array}$ & $\begin{array}{l}\text { Büyüme oranından cari açığa tek yönlü bir ilişki } \\
\text { olduğu ortaya konmuştur. Dolayısıyla, ekonomik } \\
\text { büyüme oranındaki artı̧lar cari açığın nedenidir. } \\
\text { Başka bir ifadeyle büyüme oranındaki artışın cari } \\
\text { açığını etkilediği sonucuna ulaşılmıştır. }\end{array}$ \\
\hline 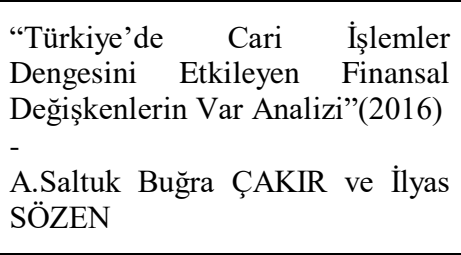 & $\begin{array}{l}\text { Bağımlı Değ: Cari Açık } \\
\text { Bağımsız Değ: Ekonomik } \\
\text { Büyüme, Reel Efektif Döviz } \\
\text { Kuru, } \\
\text { Reel Faiz Oranı, Dış Borç } \\
\text { Oranı, Para Arzı ve Enflasyon } \\
\text { Oranı }\end{array}$ & $\begin{array}{r}\text { ve } \\
\text { Nedensellik }\end{array}$ & $\begin{array}{l}\text { Dış borcun, enflasyonun ve reel döviz kurunun } \\
\text { artmasının cari açığı artırdığı, para arzının ise cari } \\
\text { açığı azalttığı sonucuna ulaşılmıştır. }\end{array}$ \\
\hline $\begin{array}{l}\text { “Türkiye'de Cari Açı̆̆ı Belirleyen } \\
\text { Faktörler ve Cari Açığı Azaltmada } \\
\text { Alternatif Enerji Kaynaklarının } \\
\text { Rolü: VAR Modeli”(2017) } \\
- \\
\text { Necati ÇİFTÇİ } \\
\text { Merve EŞMEN }\end{array}$ & $\begin{array}{l}\text { Bağımlı Değ: Cari Açık } \\
\text { Bağımsı Değ: Tasarruf, } \\
\text { Bütçe Açı̆ı, Dış Ticaret } \\
\text { Açığı, Döviz Kuru, GSYH, } \\
\text { Büyüme Oranı, D1ş Borç } \\
\text { Stoku, Para Arzı, Doğrudan } \\
\text { Yabancı ve Portföy } \\
\text { Yatırımları, Enerji Fiyatları }\end{array}$ & $\begin{array}{l}\text { VAR Model, Johansen } \\
\text { Eşbütünleşme ve } \\
\text { Granger Nedensellik } \\
\text { Testleri }\end{array}$ & $\begin{array}{l}\text { GSYH ve döviz kurunun cari açığın nedeni } \\
\text { olduğuna yönelik bulgulara ulaşılmıştır. }\end{array}$ \\
\hline
\end{tabular}

Kaynak: Çalışmada faydalanılan kaynaklardan derlenerek tarafımızdan hazırlanmıştır.

Kwalingana ve Nkuna, yaptıkları çalıșmada Malawi'nin 1980-2006 dönemine ait verilerini kullanarak cari açığını belirleyicilerini incelemişlerdir. Çalışmanın sonucunda dış borç stoku, reel efektif döviz kuru ve dış ticaret dengesi ile cari işlemler dengesi arasında pozitif, dışa açıklık oranı ile cari işlemler dengesi arasında ise negatif bir ilişki olduğu sonucuna ulaşmışlardır(Kwalingana ve Nkuna,2009: 1415).

Erdoğan ve Bozkurt, yaptıkları çalışmada Türkiye'nin 1990-2008 dönemine ait verilerini kullanarak cari açığın belirleyicilerinin neler olduğunu araştırmışlardır. Çalışmanın sonucunda cari açık ile para arzı ve petrol fiyatları ile arasında pozitif, ihracatın ithalatı karşılama oranı arasında ise negatif ilişki olduğu sonucuna ulaşmışlardır(Erdoğan ve Bozkurt, 2009: 158-159).

Bayraktutan ve Demirtaş, yaptıkları çalışma ile gelişmekte olan 19 gelişmekte ülkeden 1980-2006 dönemine ait verilerden faydalanarak cari açığın belirleyicilerini incelemişlerdir. Çalışmanın sonucunda yatırım, kamu harcamaları ve büyüme oranlarında meydana gelecek artışın cari açığı artırdığı, dışa açıklık oranının, dış ticaret dengesindeki iyileşmenin, dünya büyüme oranının ve dünya faiz oranlarındaki artışın ise cari açığı azalttığı sonucuna ulaşmışlardır(Bayraktutan ve Demirtaş, 2011: 1).

Yurdakula ve Uçar, yaptıkları çalışmada Türkiye'de cari açık ile ekonomik büyüme arasındaki ilişkiyi incelemişlerdir. Çalışmanın sonucunda büyüme oranından cari açığa tek yönlü bir ilişki olduğunu, ekonomik büyüme oranındaki artışların cari açığın nedeni olduğunu ortaya koymuşlardır. Başka bir ifadeyle büyüme oranındaki artışın cari açığı etkilediği sonucuna ulaşmışlardır(Yurdakula ve Uçar, 2015: 107).

Çakır ve Sözen, yaptığı çalışma ile Türkiye'de cari işlemler dengesini belirleyen finansal değişkenlerin neler olduğunu araştırmışlardır. Çalışmanın sonucunda dış borç, enflasyon ve reel döviz kuru arttığında ülkedeki cari açığın da arttığını, para arzının ise cari açığı azalttığı sonucuna ulaşmışlardır(Çakır ve Sözen, 2016: 19).

Çiftçi ve Eşmen, yaptıkları çalışmada Türkiye'de cari açığın belirleyicilerini incelemişlerdir. Çalışmanın sonucunda GSYH ve döviz kurunun cari açı̆̆ın nedeni olduğu sonucuna ulaşmışlardır(Çiftçi ve Eşmen, 2017, 83).

\section{Yöntem ve Uygulama}

\subsection{Veri Seti}

Çalışmada Türkiye ekonomisinin 1990-2018 dönemine ait yıllık verileri Dünya Bankası, TCMB ve TÜİK sitelerinden kullanılarak cari açığın belirleyicileri incelenmiştir. Bu kapsamda literatürde yapılan çalışmalar incelenerek cari 
işlemler dengesinin belirleyicilerinin neler olduğu tespit edilerek veriler temin edilmiştir. Literatürde yer alan değişkenler modele dâhil edilmiş fakat sadece 6 değişken

Tablo 3. Modelde Yer Alan Değişkenler anlamlı sonuç vermiştir. Söz konusu 6 değişken aşağıdaki Tablo 3 'te detayları ile gösterilmiştir.

\begin{tabular}{lccc}
\hline Değişken Çeşitleri & Semboller & Değişkenler & Açıklama \\
\hline Bağımlı Değişken & CID & Cari İşlemler Dengesi & Cari İşlemler Dengesi/GSYH \\
\hline & İHR & İhracatın İthalatı Karşılama & İhracat/ İthalat
\end{tabular}

Bağımsız
Değişkenler

DAO

DYY

PY
Dışa Açıklık Oranı

Doğrudan Yabancı Yatırımlar

Portföy Yatırımları
Dış Ticaret Hacmi/GSYH

Doğrudan Yabancı Yatırımlar

Portföy Yatırımları
Çalışmada bağımlı değişken olarak Khan ve Knight(1983), Chinn ve Prasd(2000), Aristovnik(2006), Gulzar ve diğerleri(2007), Kwalingana ve Nkuna(2009) ve Morsy(2009)'nin yaptıkları çalışmalardan esinlenerek cari işlemler dengesi kullanılmıştır. Literatürde bağımlı değişken olarak cari açığın da kullanıldığı görülmekte olup modelde anlamlı sonuç verdiği için cari işlemler dengesi kullanılmıştır.

Çalışmada bağımsız değişken olarak literatürde yer alan ekonomik büyüme, kişi başına düşen gelir, nispi gelir, tasarruf, dış ticaret dengesi, dışa açıklık oranı, ihracatın ithalatı karşılama oranı, reel döviz kuru, dış borç oranı, doğrudan yabancı yatırımlar, portföy yatırımları, petrol fiyatları, enflasyon oran1, reel faiz oran1, bütçe dengesi, kamu harcamaları, finansal derinlik ve para arzı değişkenleri test edilmiştir. Çalışmanın sonucunda 19902018 dönemi Türkiye ekonomisine ait veriler 1şı̆̆ında istatistiksel olarak anlamlı bir model tespit edilmiştir. Modelde bir bağımlı değişken ve dört bağımsız değişken

olmak üzere toplam beş değişken yer almıştır. İhracatın ithalatı karşılama oranı(İHR), dışa açıklık oranı(DAO), doğrudan yabancı yatırım(DYY), portföy yatırımları(PY) modelde yer alan değişkenlerdir. Çalışmada kullanılan bağımsız değişkenler Khan ve Knight(1983), Debelle ve Farequee(1996), Calderon ve diğerleri(1999), Chinn ve Prasad(2000), Aristovnik(2006), Erdoğan ve Bozkurt(2009), Morsy(2009), Kwalingana ve Nkuna(2009), Bayraktutan ve Demirtaş(2011), Çiftçi ve Eşmen(2017)'in yaptıkları çalışmalardan esinlenerek kullanılmıştır.

İhracatın İthalatı Karşılama Oranı: İhracat ve ithalat cari işlemler dengesinin belirlenmesinde önemli bir role sahiptir. Bir ülkenin ihracatı ve ithalatı iç talebe, üretim kapasitesine ve döviz kuruna göre değişiklik göstermektedir. İhracat hacmindeki artışın cari işlemler dengesini olumlu, ithalat hacmindeki artışın ise olumsuz etkilemesi beklenmektedir. Fakat ihracattaki artışın ithalattaki artıştan daha fazla olması durumunda cari işlemler dengesi olumlu yönde etkilenmektedir. İhracat hacmi, ithalat hacmi ile aynı oranda artar ya da ithalat hacminden daha az artarsa cari işlemler dengesi olumsuz etkilenecek, dolayısıyla cari açık ortaya çıkacaktır(Gulzar v.d., 2007: 666).

Erdoğan ve Bozkurt, Türkiye özelinde yaptığı çalışmanın sonucunda ihracatın ithalatı karşılama oranı ile cari açık arasında negatif ilişki bulmuşlardır(Erdoğan ve Bozkurt, 2009: 158). Bozgeyik ve Kutlu, yaptıkları çalışmanın sonucunda ihracatın ithalatı karşılama oranı ile cari işlemler dengesi arasında pozitif ilişki bulmuşlardır. Başka bir ifadeyle ihracatın ithalattan daha fazla artmasının cari açığı azalttığ 1 sonucuna ulaşmışlardır(Bozgeyik ve Kutlu, 2019: 17).

Dışa Açıklık Oranı: Dışa açıklık oranı dış ticaret hacminin yani, ülkenin ihracat ve ithalatının toplam değerinin GSYH bölünmesiyle elde edilen değeri göstermektedir. Bu gösterge ülke ekonomisinin dışarıya açıklık seviyesini göstermektedir. Dışa açıklık oranının cari işlemler dengesi üzerine etkisi belirsizdir. Çünkü dışa açıklık oranının hesaplanmasında kullanılan dış ticaret hacminin büyümesi ihracattan kaynaklı büyüme ise cari işlemler dengesi üzerinde olumlu etkisi beklenirken, ithalattan kaynaklı büyüme ise cari işlemler dengesi üzerinde olumsuz etki beklenmektedir. Dolayısıyla dışa açıklık oranın etkisi ithalat ve ihracata bağlı olmak üzere değişkenlik göstermektedir. Literatürde yapılan çalışmalar incelendiğinde dişa açıklık oranın cari işlemler dengesi ya da cari açık üzerinde etkisi ile ilgili olarak olumlu ve olumsuz olmak üzere farklı sonuçların bulunduğu görülmüştür.

Chinn ve Prasad, yaptıkları çalışmanın sonucunda dışa açıklık oranı ile cari işlemler dengesi arasında negatif ilişki bulmuşlardır. Başka bir ifadeyle, dışa açıklık oranındaki artışın cari açı̆̆ı artırdığını ortaya koymuşlardır(Chinn ve Prasad, 2000: 26). Kwalingana ve Nkuna, yaptıkları çalışmanın sonucunda dışa açıklık oranı ile cari işlemler dengesi arasında negatif ilişki bulmuşlardır. Başka bir ifadeyle, dışa açıklık oranındaki artışın cari açığı artırdığı sonucuna ulaşmışlardır(Kwalingana ve Nkuna, 2009: 14). Aristovnik yaptığı çalışmanın sonucunda dışa açıklık oranı 
ile cari işlemler dengesi arasında pozitif ilişki bulmuştur. Başka bir ifadeyle, dışa açıklık oranındaki artışın cari açı̆̆ı azalttığı sonucuna ulaşmıştır(Aristovnik, 2006: 11). Bayraktutan ve Demirtaş, yaptıkları çalışmanın sonucunda dışa açıklık oranındaki artışın cari açığı azalttığını ortaya koymuşlardır(Bayraktutan ve Demirtaş, 2011: 1).

Doğrudan Yabancı Yatırımlar ve Portföy Yatırımları: Doğrudan yabancı yatırımlar ve portföy yatırımları özellikle az gelişmiş ve gelişmekte olan ülke ekonomileri için cari işlemler dengesinin en önemli belirleyicilerindendir. Şöyle ki; bir ülkeye giren döviz miktarı çıkan döviz miktarından az ise o ülkede cari açık bulunmaktadır(Husted, 1992: 160).

Doğrudan yabancı yatırımların milli gelirin artması, sermaye birikiminin artması ve istihdamın artması gibi çeşitli makroekonomik göstergeler üzerinde olumlu yönde etkileri bulunmaktadır. Doğrudan yabancı yatırımlar ile ihracatı artırılması ve ithalat azaltılması, dış ticaret açığının kapatılmasında beklenen olumlu katkı sağlanabilirse, ödemeler dengesi dolayısıyla da cari işlemler dengesinin de bu durumdan olumlu yönde etkilendiği görülecektir(Çinko, 2009: 124).

Aristovnik yaptığı çalışmanın sonucunda doğrudan yabancı yatırımlar ile cari işlemler dengesi arasında istatistiksel olarak anlamlı ve negatif ilişki bulmuştur. Başka bir ifadeyle, doğrudan yabancı yatırımların artmasının cari açığı artırdığ 1 sonucuna ulaşmıştır(Aristovnik, 2007: 12). Mercan ve Yurttançıkmaz, yaptıkları çalışmanın sonucunda doğrudan yabancı yatırımların uzun dönemde cari açık üzerinde negatif etkisi olduğunu başka bir ifadeyle, doğrudan yabancı yatırımların artmasının cari açığı azalttığını ortaya koymuşlardır (Mercan ve Yurttançıkmaz, 2013: 57). Göçer ve Peker, yaptıkları çalışmada Türkiye, Çin ve Hindistan için 1980-2011 dönemine ait verileri kullanarak doğrudan yabancı yatırımların cari işlemler dengesi üzerindeki etkisini incelemişlerdir. Çalışmanın sonucunda doğrudan yabancı yatırımların artmasının Türkiye ve Hindistan'da cari açığı azalttığı, Çin'de ise cari fazlayı artırdığı sonucuna ulaşmışlardır(Göçer ve Peker, 2014: 106-107). Bozgeyik ve Kutlu, yaptıkları çalışmanın sonucunda doğrudan yabancı yatırımlar ile cari işlemler dengesi arasında pozitif ilişki bulmuşlardır. Başka bir ifadeyle, doğrudan yabancı yatırımların artmasının cari açığı azalttığı sonucuna ulaşmışlardır(Bozgeyik ve Kutlu, 2019: 17). Kim ve Kim, yaptıkları çalışmanın sonucunda cari işlemler ile sermaye girişleri arasında çift yönlü nedensellik bulmuşlar ve sermaye girişinin, döviz kurunun değer kazanmasına neden olduğunu, bununda cari işlemler dengesini kötüleştirdiğini ortaya koymuşlardır(Kim ve Kim, 2011: 497). Ayhan, yaptığı çalışmada BRICS-T ülkelerinde portföy yatırımları ile cari açık arasındaki ilişkiyi incelemiştir. Çalışmanın sonucunda portföy yatırımları ile cari işlemler dengesi arasında pozitif ilişki bulmuştur(Ayhan, 2014: 72). Bayar ve diğerleri yaptıkları çalışmada Türkiye'de cari açı̆̆ın belirleyicilerini incelemişlerdir. Çalışmanın sonucunda portföy yatırımlarının .cari işlemler dengesinin Granger nedeni olduğunu ortaya koymuşlardır(Bayar v.d., 2014: 451).

\subsection{Yöntem}

Çalışmanın model tahmin aşamasında eldeki veriler 1şığında bir bağımlı ve birden fazla bağımsız değişken olmasından dolayı çoklu regresyon modeli kullanılmış, parametreler ise En Küçük Kareler Yöntemi(EKK) ile tahmin edilmiştir. EKK yönteminin tercih edilmesinin sebebi, belli varsayımlara sahip olması durumunda güvenilir tahminler vermesindendir. EKK yöntemi, sabit parametre ve eğim parametrelerinin tahmin edilmesinde sık kullanılan yöntemlerden biridir. EKK yönteminin kullanıldığı regresyon modelinde cari işlemler dengesi değişkeni bağımlı, diğer değişkenler bağımsızdır. EKK sonucu ortaya çıkan modelin fonksiyonel şekli aşağıdaki gibi gerçekleşmiştir.

\section{Model :}

$\mathbf{C A D}=-7.485952+7.49 * \mathrm{PY}+0.150381 * \mathrm{IHR}-$ $0.089257 * \mathrm{DAO}+0.000229 * \mathrm{DYY}$

EKK yönteminin varsayımların sinanmasında, verilerin normal dağılıp dağılmadığını incelemek için Jarque-Bera (J-B) normallik testi, değişen varyans olup olmadığını incelemek için Breusch-Pagan-Godfrey testi, otokorelasyon olup olmadığını incelemek için BreuschGodfrey serisel korelasyon LM testi yapılmıştır. Diğer taraftan serilerin durağanlığını incelemek için Dickey ve Fuller (1979) tarafindan geliştirilen Genişletilmiş DickeyFuller (ADF) birim kök testi kullanılmıştır.

Sonuç olarak söz konusu bu varsayımlar test edilmiş ve EKK yöntemini uygulamak için bir problem görülmemiştir.

\subsection{Bulgular}

EKK testine geçmeden önce, serilerin birim kök testleri incelenmiştir. ADF birim kök testini yapmadan önce serilerin grafiklerinden kırılganlıkları incelenmiş ve 19902018 yılları arası serilerin bazılarında kırılganlıkların olduğu görülmektedir. Buna sebep olarak da 1994 ve 2001-2002 yılında Türkiye'de yaşanan ve 2008 yılında ABD başlayıp dünyaya yayılan kriz sebep olarak gösterilebilir. Dolayısıyla bazı seriler için kırılmalı bazı serileri için ise normal birim kök testi uygulanmıştır. Model için birim kök testi sonuçları Tablo 4'te gösterilmiştir. 
Tablo 4. Modelde Yer Alan Değişkenlerinin ADF Birim Kök Test Sonuçları

\begin{tabular}{ccccccc}
\hline \multirow{2}{*}{ Değişken } & & ADF Test & \multicolumn{3}{c}{ Kritik Değerler } & \multirow{2}{*}{ Prob. } \\
\cline { 4 - 6 } & & İstatistiği & $\mathbf{1 \%}$ & $\mathbf{5 \%}$ & $\mathbf{1 0 \%}$ & \\
\hline CAD & Sabit ve Trend & -5.828 & -5.347 & -4.859 & -4.607 & $<0.01$ \\
DAO & Sabit ve Trend & -5.119 & -5.347 & -4.859 & -4.607 & 0.0230 \\
İHR & Sabit ve Trend & -6.738 & -5.347 & -4.859 & -4.607 & $<0.01$ \\
DYY & Sabit & -7.257 & -4.949 & -4.443 & -4.193 & $<0.01$ \\
PY & Hiçbiri & -2.776 & -2.650 & -1.953 & -1.609 & 0.0073
\end{tabular}

Tablo 4 incelendiğinde modele dâhil olan değişkenlerin tamamının \%5 anlamlılık düzeyinde durağan olduğu görülmektedir. Değişkenlerin durağanlığını test ettikten sonra değişkenlerin varsayımlardan sapmaları incelenmiştir. $\mathrm{Bu}$ kapsamda normallik, otokorelasyon, çoklu doğrusal bağlılık ve sabit varyans varsayımları incelenmiştir.

Normallik varsayımı, hata terimlerinin ortalamasının sıfir ve varyanslarının sabit olduğu durumda sağlanmaktadır.
Normallik varsayımı, parametreler için güven aralıkları oluşturulmasında ve anlamlılık testlerinde gerekmektedir. Model için normallik varsayımı Jargue-Bera Normallik testi ile incelenmiştir. Hipotezler ve Jargue-Bera Normallik testi sonuçları Şekil 1'deki gibidir.

$\mathrm{H}_{0}$ : Kalıntılar normal dağılıma uymaktadır.

$\mathrm{H}_{1}$ : Kalıntılar normal dağılıma uymamaktadır.

Şekil 1. Jargue-Bera Normallik Testi

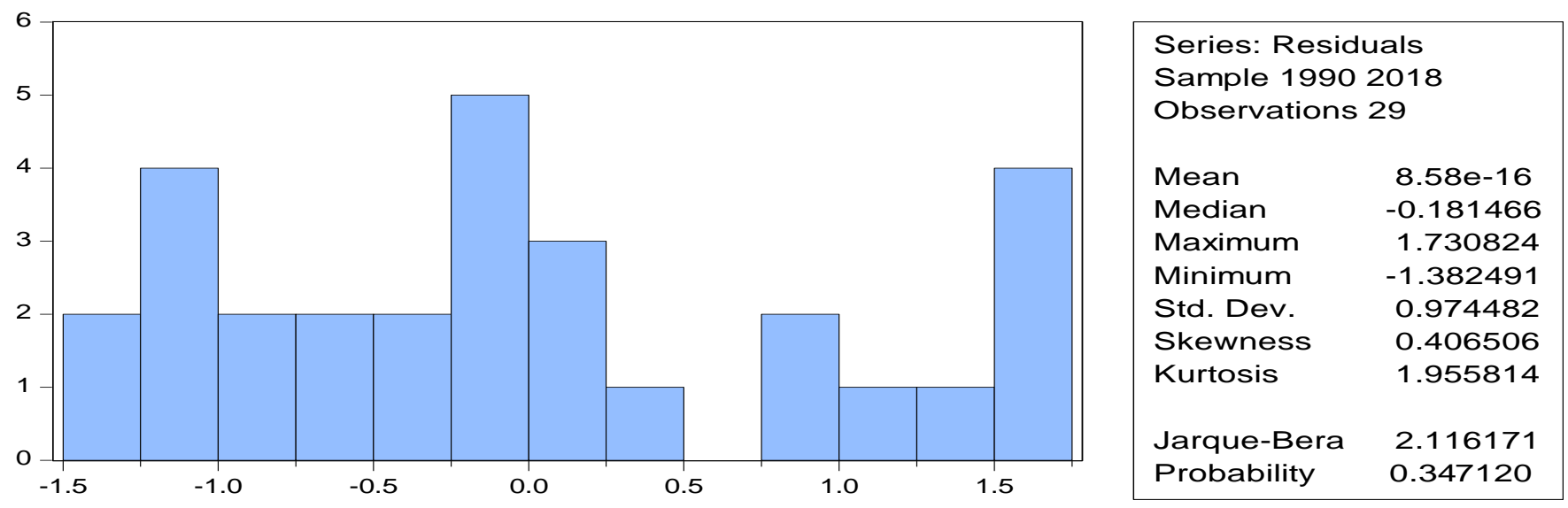

Şekil 2. Otokorelasyon Karar Aşaması

Şekil 1'de de görüldüğü üzere; Probability=0.347120> 0.05 olduğu için $\mathrm{H}_{0}$ hipotezi reddedilememektedir. Dolayısıyla bu durum modelin hata terimlerinin normal dağıldığını göstermektedir.

Diğer bir varsayım olan otokorelesyon, birbirini izleyen hata terimleri arasında ilişki olması durumunda ortaya çıkmaktadır. Otokorelasyon olması durumunda tahmin edilen katsayı değerleri sapmalı, $t$ testi ve $F$ testi sonuçları olması gerekenden büyük çıkarak güvenilirlik ortadan kalkmaktadır. Otokorelasyon varsayımını test etmek için Durbin Watson testi ve daha sonra çıkan sonuca göre Breusch- Godfrey Serial Correlation LM Testi uygulanmıştır. Şekil 2 otokorelasyon karar aşamasını göstermektedir.

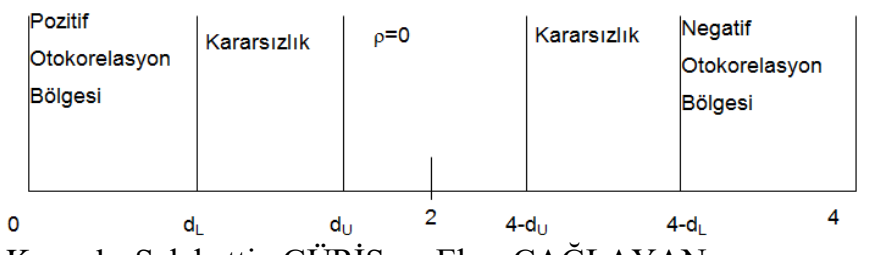

Kaynak: Selahattin GÜRİŞ ve Ebru ÇAĞLAYAN,

Ekonometri, 2013, s. 496.

Durbin-Watson kritik değerleri Savin-White tablosuna göre, 29 gözlem ve 3 bağımsı değişken için $\mathrm{d}_{\mathrm{U}}=1.650$ iken $\mathrm{d}_{\mathrm{L}}=1.198$ olarak hesaplanmıştır. İlk modelin Durbin Watson değeri ise 1.488 olarak hesaplandığından dolayı Şekil 2'ye göre pozitif otokorelasyon kararsızlık bölgesinde kalmaktadır. O halde Breusch-Godfrey Serial 
Correlation LM Testi bize otokorelasyonun olup olmadı̆̆ ile ilgili daha net sonuçlar verecektir.

Tablo 5. Breusch-Godfrey Otokorelasyon LM Testi

\begin{tabular}{lclc}
\hline F-statistic & 1.070307 & Prob. F(2,22) & 0.3601 \\
Obs*R-squared & 2.571508 & Prob. Chi-Square(2) & 0.2764 \\
\hline
\end{tabular}

$\mathrm{H}_{0}$ : Otokorelasyon vardır.
$\mathrm{H}_{1}$ : Otokorelasyon yoktur.

Breusch-Godfrey Otokorelasyon LM Testi sonuçları incelendiğinde, Prob. Chi-Square(2) değeri (0.2764)>0.05 olduğu için $\mathrm{H}_{0}$ hipotezi reddedilmektedir. Başka bir ifadeyle otokorelasyon görülmemektedir.

Çoklu doğrusal bağlılık, bağımsız değişkenler arasında doğrusal bir ilişkinin olması durumunda ortaya çıkmaktadır. Bağımsız değişkenler arasında doğrusal bir ilişkinin olması katsayı tahminlerinin yanlış tahmin edilmesine neden olmaktadır. Dolayısıyla modelde çoklu doğrusal bağlılık olmaması başka bir ifadeyle, bağımsız değişkenler arasında doğrusal bir ilişki olmaması gerekmektedir. Çoklu doğrusal bağlılık testi, variance inflation factor (VIF) ile yapılmaktadır. Modelde çoklu doğrusal bağlılık olup olmadığına bakmak için de Centered VIF değerine bakılmaktadır. Centered VIF değeri için kesin net bir yöntem olmamakla birlikte genellikle 5'den düşük veya 10 'dan düşük değerler uygun kabul edilmektedir(Craney ve Surles, 2002: 393).

Tablo 6. Çoklu Doğrusal Bağlantı Testi (VIF)

\begin{tabular}{llll}
\hline Variable & $\begin{array}{l}\text { Coefficient } \\
\text { Variance }\end{array}$ & Uncentered VIF & Centered VIF \\
\hline C & 3.869879 & 101.2979 & NA \\
PY & $3.77 \mathrm{E}-10$ & 1.613215 & 1.285627 \\
IHR & 0.000952 & 103.1359 & 1.183865 \\
DAO & 0.001576 & 57.57621 & 2.256211 \\
DYY & $1.81 \mathrm{E}-09$ & 3.565727 & 1.814452 \\
\hline
\end{tabular}

Tablo 6'dan da görüldüğü üzere parametrelerin Centered VIF değerleri 5'in altında hesaplanmıştır. Dolayısıyla çoklu doğrusal bağlantının önemsiz olduğu söylenebilmektedir.

EKK yönteminin varsayımlarından bir diğeri de hata terimlerinin sabit varyanslı olmasıdır. Hata terimleri sabit varyanslı olmadığı durumda EKK tahmincisinin hesaplanan varyans ve standart hataları yanlış hesaplanmaktadır. $\mathrm{Bu}$ durum $\mathrm{t}$ ve $\mathrm{F}$ istatistik değerlerinin sapmalı sonuçlar vermesine ve testlerin güvenilirliğinin ortadan kalkmasına neden olmaktadır. Sabit varyans varsayımını test etmek için Breusch-Pagan-Godfrey testi uygulanmış olup, hipotezler ve test sonuçları Tablo 7'de gösterilmiştir.

$$
\begin{aligned}
& \mathrm{H}_{0} \text { : Sabit varyans vardır. } \\
& \mathrm{H}_{1} \text { : Değişen varyans vardır. }
\end{aligned}
$$

Tablo 7. Sabit Varyans Testi

\begin{tabular}{cccc}
\hline \multicolumn{4}{c}{ Heteroskedasticity Test: Breusch-Pagan-Godfrey } \\
\hline F-statistic & 1.749266 & Prob. F(4, 24) & 0.1722 \\
Obs*R-squared & 6.546261 & Prob. Chi-Square(4) & 0.1619 \\
Scaled explained SS & 2.142710 & Prob. Chi-Square(4) & 0.7095 \\
\hline
\end{tabular}

Breusch-Pagan-Godfrey testi sonuçlarını incelendiğinde prob. değerlerinin 0,05 ' den büyük olduğu görülmektedir. $\mathrm{Bu}$ da $\mathrm{H}_{0}$ hipotezinin reddedilmediğini ve sabit varyans olduğunu göstermektedir.

Sonuç olarak En Küçük Kareler(EKK) yöntemini uygulamak için gerekli varsayımların sağlandığı görülmüştür. Model tahmini için EKK testi uygulanmış ve araştırmanın testleri \%95 güven aralığ 1 düzeyinde test edilmiştir. Modelin genel tahmini Tablo 8'deki gibi gerçekleşmiştir. 
Tablo 8. Modelin Genel Tahmini

\begin{tabular}{|c|c|c|c|c|}
\hline Bağımlı Değiş̧ken & \multicolumn{4}{|c|}{ Cari İşlemler Dengesi } \\
\hline Yöntem & \multicolumn{4}{|c|}{ En Küçük Kareler Yöntemi } \\
\hline Örneklem & \multicolumn{4}{|l|}{$1990-2018$} \\
\hline Gözlem Sayısı & 29 & & & \\
\hline Değişkenler & Katsayılar & Standart Hata & t-İstatistik & Olasilık \\
\hline $\mathbf{C}$ & -7.485952 & 1.967201 & -3.805383 & 0.0009 \\
\hline PY & 7.49E-05 & $1.94 \mathrm{E}-05$ & 3.860365 & 0.0007 \\
\hline İHR & 0.150381 & 0.030862 & 4.872629 & 0.0001 \\
\hline DAO & -0.089257 & 0.039703 & -2.248119 & 0.0340 \\
\hline DYY & 0.000229 & $4.26 \mathrm{E}-05$ & 5.383032 & 0.0000 \\
\hline R-squared & 0.865810 & Mean dependent var & & -2.962036 \\
\hline Adjusted R-squared & 0.843445 & S.D. dependent var & & 2.660202 \\
\hline S.E. of regression & 1.052561 & Akaike info criterion & & 3.095916 \\
\hline Sum squared resid & 2.658925 & Schwarz criterion & & 3.331656 \\
\hline Log likelihood & -3.989078 & Hannan-Quinn criter. & & 3.169747 \\
\hline F-statistic & 3.871284 & Durbin-Watson stat & & 1.488337 \\
\hline Prob(F-statistic) & 0.000000 & & & \\
\hline
\end{tabular}

Birinci modelin genel tahmini incelendiğinde 1990-2018 dönemine ait veriler kullanılarak ve EKK yöntemi uygulanarak dört bağımsız (PY, İHR, DAO, DYY) ve bir bağımlı(CAD) olmak üzere istatistiksel olarak anlamlı bir model bulunmuştur. Modelin genel anlamlılığını gösteren $\mathrm{F}$ istatistik değeri incelendiğinde Prob(F-statistic) $<0.05$ olduğu ve modelin \% 95 güven düzeyinde genel olarak anlamlı olduğu görülmektedir. Parametrelerin anlamlılığını gösteren $\mathrm{t}$ istatistik değerleri incelendiğinde ise sabit katsayı ve bağımsız değişkenlerin prob. değerlerinin 0,05 'ten küçük olduğu, dolayısıyla \%95 güven düzeyinde anlamlı olduğu görülmektedir. Bununla birlikte modelin düzeltilmiş belirlilik katsayısı 0,843445 olarak gerçekleşmiştir. Bu katsayı, söz konusu dört bağımsız değişkenin cari işlemler dengesi değişkenini yaklaşık \%84 oranında açıkladığını göstermektedir

Bağımsız değişkenlerin katsayıları incelendiğinde ise portföy yatırımları ile cari işlemler dengesi arasında istatistiksel olarak anlamlı ve pozitif ilişki bulunmuştur. Portföy yatırımlarındaki bir birimlik artışın cari işlemler dengesini 7 birim artırdığ 1 görülmektedir. Başka bir ifadeyle, portföy yatırımlarının artmasının cari açığı azalttığı sonucuna ulaşılmıştır. İhracatın ithalatı karşılama oranı ile cari işlemler dengesi arasında istatistiksel olarak anlamlı ve pozitif ilişki bulunmuştur. İhracatın ithalatı karşılama oranındaki bir birimlik artışın cari işlemler dengesini 0.15 birim artırdığı görülmektedir. Başka bir ifadeyle, ihracatın ithalatı karşılama oranının artmasının cari açığı azalttığı sonucuna ulaşılmıştır. Dışa açıklık oranı ile cari işlemler dengesi arasında istatistiksel olarak anlamlı ve negatif ilişki bulunmuştur. Dışa açıklık oranında meydana gelecek bir birimlik artışın cari işlemler dengesini yaklaşık 0.09 birim azalttığı görülmektedir. Başka bir ifadeyle, dışa açıklık oranında meydana gelecek artışın cari açığı artırdığı görülmektedir. Doğrudan yabancı yatırımlar ile cari işlemler dengesi arasında istatistiksel olarak anlamlı ve pozitif ilişki bulunmuştur. Doğrudan yabancı yatırımlarda meydana gelecek bir birimlik artışın cari işlemler dengesini 0.000229 birim artırdığı görülmektedir. Başka bir ifadeyle, doğrudan yabancı yatırımların artmasının cari açığı azalttığı sonucuna ulaşılmıştır. Bulunan sonuçlar Chinn ve Prasad(2000), Kwalingana ve Nkuna(2009), Erdoğan ve Bozkurt(2009), Ayhan(2014), 
Bozgeyik ve Kutlu(2019)'nun yaptıkları çalışmaların sonuçları ile benzerlik göstermektedir.

\section{Sonuç}

Tarihsel olarak ele alındığında Türkiye ekonomisinin en önemli sorunlarının başında cari açık sorunun geldiği görülmektedir. Cari açığın GSYH oranının belli bir değer üzerine çıkması kriz belirtisi olacağından dolayı ekonomi yönetimlerinin en önemli amaçlarından birisi cari açık sorununu çözmek olmuştur. Bu çalışmada Türkiye'nin cari açığının belirleyicileri 1990-2018 dönemine ait veriler kullanılarak ve En Küçük Kareler Yöntemi yardımıyla incelenmiştir. EKK testini yapmadan önce değişkenlerin durağanlıkları incelenmiş ve değişkenlerin durağan olduğu görülmüştür. Ardından EKK yöntemini uygulayabilmek için gerekli varsayımlar test edilmiş ve bütün varsayımların sağlandığı görülmüştür. Sonuçlar, Türkiye'de cari açığın belirlenmesinde önemli olan değişkenlerin portföy yatırımları, doğrudan yabancı yatırımlar, dışa açıklık oranı ve ihracatın ithalatı karşılama oranı olduğunu ortaya koymaktadir.

Çalışmanın sonucunda doğrudan yabancı yatırım ve portföy yatırımlarının artmasının cari açığı azalttığı sonucuna ulaşılmıştır. Burada şunu özellikle belirtmek gerekir ki; söz konusu bu yatırımlar uzun dönem yatırımları olduğu zaman bu sonuç geçerli olmaktadır. Kısa dönemli sermaye girişleri ile cari açığın finanse edilmesi risklidir. Çünkü kısa dönemli sermaye hareketleri ülkedeki risk ve belirsizliklere karşı duyarlı olup, oynak bir yapıya sahiptir. Bu durumda ekonominin kırılganlık düzeyini artırmaktadır.

Dışa açıklık oranının artmasının cari açığı artırdığı sonucuna ulaşılmıştır. 1990-2018 dönemine ait veriler incelendiğinde dışa açıklık oranının iki katından daha fazla arttığ görülmektedir. Yine söz konusu dönem için veriler incelendiğinde dıș ticaret hacmindeki büyümenin genel olarak ithalattan kaynaklandığı ve cari açığın artmasının başlica sebebi olduğu görülmektedir.

İhracatın ithalatı karşılama oranının artmasının cari açığı azalttığı sonucuna ulaşılmıştır. İhracatın ithalatı karşılama oranı, ülkemizde özellikle ulusal para biriminin değer kaybettiği, ithalatın pahalılaşıp ihracatın ucuzladığı yıllarda artma eğiliminde olmuştur. Bu durum da doğal olarak cari açığın azalmasına sebep olmuştur. Son yıllarda kurda yaşanan dalgalanmalar ve ulusal para biriminin değer kaybetmesi sonucu ihracatın ithalatı karşılama oranının \%75 seviyelerine kadar çıktığı görülmektedir. Dönem dönem kurda yaşanan bu dalgalanmalar ihracatın ithalatı karşılama oranının artmasına ve ülkeye döviz girişinin artmasına sebep olmuş, dolayısıyla da cari açık tarafında azalmalar ortaya çıkmıştır.

Sonuç olarak, çalışmanın neticesinde bulunan bulgular ile literatürde yapılan çalışmalar arasında uyum ve benzerlik olduğu görülmüştür. Çıkan sonuçlara göre, Türkiye'nin cari açığın azaltılması için öncelikle ihracatın artırılıp, ithalatın azaltılması gerekmektedir. Bu kapsamda en önemli ithalat kalemi olan enerjide dışa bağımlılığını azaltılması önem arz etmektedir. Bununla birlikte üretimde yer alan ithal girdinin yurtiçinde üretiminin teşvik edilmesi de cari açığın azaltılmasına katkı sağlayacaktır. Son olarak da ülke ekonomisine yapılan doğrudan yabancı yatırım ve portföy yatırımlarının artması için gerekli düzenlemelerin yapılması ve yabancı yatırımların teşvik edilmesi önem arz etmektedir.

\section{Kaynakça}

Aristovnik, A. (2007). Short- And Medium-Term Determinants of Current Account Balances in Middle East and North Africa Countries. William Davidson Institute Working Paper Number 862.

Aristovnik, A. (2006). The Determinants and Excessiveness of Current Account Deficits in Eastern Europe and the Former Soviet Union. William Davidson Institute Working Paper Number 827.

Ayhan, D. (2014). BRICS-T Ülkelerine Yönelik Portföy Yatırımlarının Cari Açık Üzerindeki Etkisi: Dinamik Panel Veri Analizi. Niğde Üniversitesi İBF Dergisi, 7(1), 67-75.

Bayar, Y., Kılıç, C. Ve Arıca, F. (2014). Türkiye'de Cari Açı̆̆ın Belirleyicileri. C. Ü. İktisadi ve İdari Bilimler Dergisi, 15(1), 451-471.

Bayraktutan, Y. ve Demirtaş, I. (2011). Gelişmekte Olan Ülkelerde Cari Açığın Belirleyicileri: Panel Veri Analizi. Kocaeli Üniversitesi Sosyal Bilimler Enstitüsü Dergisi (22), 1-28.

Bitzis, G., Paleologos, J. M. \& Papazoglou, C. (2008). The Determinants of the Greek Current Account Deficit: The EMU Experience. Journal of International and Global Economic Studies, 1(1), 105-122.

Bozgeyik, Y. ve Kutlu, A. (2019). Türkiye'de Cari Açığın Belirleyicileri: 1992-2017 Dönemi İçin Ampirik Çalışma. Maliye Dergisi. (176). 1-26.

Calderon, C.A., Chong, A. \& Loayza, N. (1999). Determinants of Current Account Deficits in Developing Countries. World Bank Policy Research Working Paper No. 2398.

Clarida, R. H. (2007). G7 Current Account Imbalances: Sustainability and Adjustment. National Bureau of Economic Research.

Chinn, M. \& Prasad, E.S. (2000). Medium-Term Determinants Of Current Accounts In Industrial And Developing Countries: An Empirical Exploration. NBER Working Paper Serıes Working Paper 7581.

Craney, T.A. \& Surles, J. G. (2002). Model-Dependent Variance Inflation Factor Cutoff Values. Quality Engineering, 14(3), 391-403.

Çakır, A. S. B. ve Sözen, İ. (2016). Türkiye'de Cari İşlemler Dengesini Etkileyen Finansal Değişkenlerin Var Analizi. The Academic Elegance. 19-42.

Çiftçi, N. ve Eşmen, M. (2017). Türkiye'de Cari Açığ 1 Belirleyen Faktörler ve Cari Açığı Azaltmada Alternatif Enerji Kaynaklarının Rolü: VAR Modeli. Bilecik Şeyh Edebali Üniversitesi Sosyal Bilimler Enstitüsü. 2(1), 83-110. 
Çinko, L. (2009). Doğrudan Yabancı Sermaye Hareketlerinin Makroekonomik Etkileri. Marmara Üniversitesi İ.̇.B.F. Dergisi, 26(1), 117-131.

Çinko, L ve Demirci, S. (2017). Sustainability of Current Area: An Application on Turkey. Eurasian Business \& Economics Journal, 12, 148-155.

Debelle, G. \& Farequee, H. (1996). What Determinants the Currnet Account? A cross- Sectional and Panel Data Approach. IMF Working Paper, 96/58, 1-35.

Erdoğan, S. ve Bozkurt, H. (2009). Türkiye'de Cari Açığın Belirleyicileri: MGARCH Modelleri ile Bir İnceleme. Maliye Finans Yazllarl, 23(84), 135-172.

Gulzar, S, Feng, H. X. \& Yajie, W. (2007). The Current Account Balance of Pakistan 1972-2005: A Cointegration Analysis. Information Technology Journal, 6(5), 665-671.

Göçer, İ. ve Peker, O. (2014). Yabancı Doğrudan Yatırımların Cari İşlemler Dengesi Üzerindeki Etkileri: Türkiye, Çin ve Hindistan Örnekleminde Çoklu Yapısal Kırılmalı Eşbütünleşme Analizi. BDDK Bankacllık ve Finansal Piyasalar. 8(1), 87-116.

Güriş, S ve Çağlayan, E. (2013). Ekonometri: Temel Kavramlar. İstanbul: DER Yayınları.

Herwartz, H. \& Siedenburg, F. (2007). Determinants of Current Account Imbalances in 16 OECD Countries: An Out-Of-Sample Perspective. Review of World Economics, 143(2), 349-374.

Husted, S. (1992). The Emerging U.S. Current Account Deficit in the 1980s: A Cointegration Analysis, The Review of Economics and Statistics, 74(1), 159-166.
Khan, S. K. \& Knight, M.D. (1983). Determinants of Current Account Balances of Non-Oil Developing Countries in the 1970s: An Empirical Analysis. IMF Staff Papers, 30(4), 819-842.

Kım, C.-H. \& Kım, D. (2011). Do Capital Inflows Cause Current Account Deficits?. Applied Economics Letters, 18(5). 497-500.

Kwalingana, S. \& Nkuna, O. (2009). The Determinants of Current Account Imbalances in Malawi”. MPRA Paper No. 14694.

Mercan, M. ve Yurttançıkmaz, Z. Ç. (2013). Doğrudan Yabancı Yatırımlar- Cari İşlemler Açığı İlişkisi: Türkiye İçin Ampirik Bir Analiz, Bankacılar Dergisi, 24(87), 57-78.

Morsy, H. (2009). Current Account Determinants for OilExporting Countries. IMF Working Paper WP/09/28.

Yurdakula, F. ve Ucar, B. (2015). The Relationship Between Current Deficit and Economic Growth: An Empirical Study on Turkey. Procedia Economics and Finance, 26. 101-108.

Obstfeld, M. \& Rogoff, K. (1996). Foundations of International Macroeconomics, Cambridge: The MIT Press.

Peker, O. (2009). Türkiye'deki Cari Açık Sürdürülebilir mi? Ekonometrik Bir Analiz, Kocaeli Üniversitesi Sosyal Bilimler Enstitüsü Dergisi, 1(17). 164-174.

Telatar, O. M. ve Terzi, H. (2009). Türkiye'de Ekonomik Büyüme ve Cari İșlemler Dengesi İlișkisi. Atatürk Üniversitesi Iktisadi ve İdari Bilimler Fakültesi Dergisi, 23(2), 119-134. 